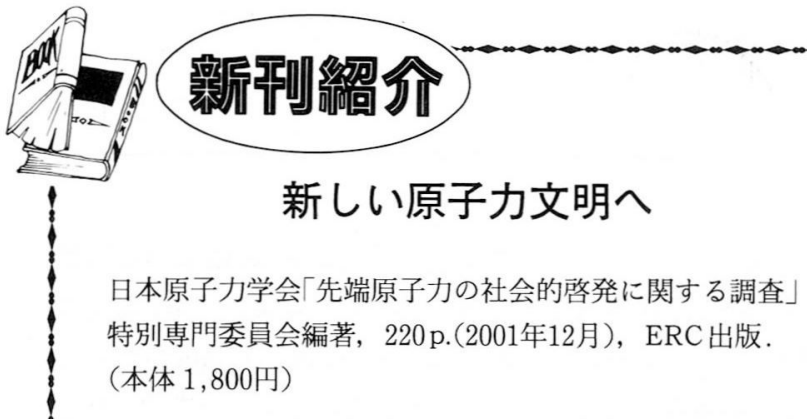

混迷の時代にこそ, 時に立ち止まっ て歴史に学ぶことの意義は大きい。そ の際には歴史を単なる知識としてでは なく, 我々が直面する困難な問題との 関わりにおいて見据えること, そして 問題を解決するための方策を, 歴史の 流れの中に位置づけて検討することが 望まれる。大きな可能性を有している にもかかわらず, 様々な困難に直面し

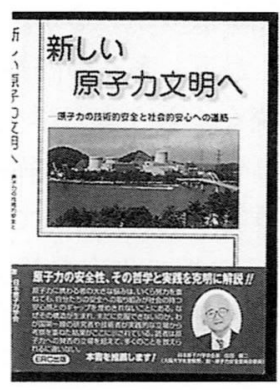
停滞が続いている原子力分野の技術者にとって，このような姿 勢で困難に立ち向かうことが今, 特に求められているといえよ う。

日本原子力学会の「先端原子力の社会的啓発に関する調査」特 別専門委員会 (主査”: 吉川栄和京都大学教授)のメンバーによっ て執筆された本書は, 上に述べたような姿勢で問題に立ち向か う際の好適な参考書であり事例集であある。歴史的視点から現 代の原子力技術を問い直しているという意味で, 他にあまり類 を見ないユニークな切り口を持った本書を一読することは, 特 に若い世代の原子力技術者にとって有意義なはずであり, 強く おすすめしたい。

本書第一章では, 「原子力発電の歴史と現状」と題して, 原子 力の持つ特性を風力発電や太陽光発電などの新エネルギーと対 比させながら解説され, それに続いて発電用の原子炉開発を中 心とした歴史が概観されている。さらに本邦では原子力廃止へ 動き始めていると認識されているスウェーデンやドイッの原子 力政策が, 実際には政治がらみで大きな流動性を有している現 状が紹介されており興味深い。

第二章「原子力安全の確保」では, 原子力施設の安全確保と放 射線に対する防護の基本的原則が説明される。安全確保の基本 指針である深層防護と多重障壁の考え方の説明は他の類書でも 見ることができるが, 本書ではその実現のための技術開発過程 が歴史を追って紹介されている点が大きな特徴である。一見簡 単に「(核反応を)止める，(炉心を)冷やす，(放射性物質を)閉 じこめる」と要約される原子力安全の基本原則を確実に実現し 保証するために, どれほど多くの地道な研究が積み重ねられて きたかが具体的に説明されている。

第三章「原子力発電所での実践」では, 第二章で導入された原 則を現実の場で実現するための仕組みや工夫が明らかにされて いる。国による原子力安全規制の概要と，それをべースとし て, 設計, 建設, 運転の各段階で注意深く追求されている安全へ の取組みが説明されるとともに，中央制御盤の改良や確率論的 安全評価の活用などの新しいトピックスについても簡潔に説明 されており, 安全を支える多くの基盤技術の理解を助けてい る。スリーマイル, チェルノブイリ,「あんじゅ」など, 重要な事 故の教訓を踏まえてなされてきた技術改良についての説明も示 唆に富む内容となっている。
第四章に「核燃料サイクル施設等の安全確保」に関する説明を 設けていることも本書独特の工夫といえよう。原子炉に比べて 語られることの少ない再処理工場, 使用済み燃料の中間眝蔵施 設, 廃衰物処分などに関わる安全確保の実態が, 原則と具体的 方策について解説されている。JCO 事故で世間の関心を集め た燃料再処理のプロセスや, 原子力技術維持の上で大きな争点 になっている廃棄物処理についての簡潔ながら要点をとらえた 記述は，当該分野の専門家ではない評者にとっても参考になる ところが多い。

「安全から安心へ」と題されている第五章は, 本書のハイライ トといえよう。原子力発電の賛否を論じる場合, 専門技術者側 が技術的安全性についてどのように説明しょうと，一般市民側 ではその説明を信じるに值するものとして容認してはすらえな い状況が各地で起こっている。この実態とその背後要因を豊富 な調査事例や分析を通して明らかにし，それを踏まえて今後の 教育を含めたリスクコミュニケーションのあり方について論じ ている。本章のような議論が十分なされないままに推移してき たことが，今日の原子力をめぐる社会的情勢をむたらしている ことを改めて痛感させられた。この章で紹介されている原子力 学会を中心とした真剣な諸活動が, 新しい流れを作り出す原動 力となることを期待したい。

冒頭にも記したように本書は，原子力技術者が自分の立脚点 を省みつつ未来を展望するための参考書に適しているが，それ だけではなく原子力を専門とはしない様々な立場の社会人に とってあ有意義な資料である。第五章に記されているょうに, 現代社会では,「人々は自分の生命や生活に影響を与える事柄 を自ら決定する権利を持っており, その決定に必要な情報を得 る権利を有している」はずである。その権利が的確に行使され るためには非専門家である各個人が, 適正に意思決定できるた めの基本的な知識を有していることが望まれる。本書の記述は 平明であり，参考図面や参考文献などの記載もおおむね適切に なされている。多少の根気は必要かも知れないが, 非専門家で あっても本書を通読し概略を把握することは十分可能であろ う。

本書をきっかけとして, 専門家と非専門家の真摰な対話が実 現することを心から念願して結びとする。

（東北大·北村正晴）

\section{核融合炉工学概論 未来エネルギーへの挑戦}

関 昌弘編, 250 p.(2001年 9 月), 日刊工業新聞社. (本体 3,200 円)

核融合炉の開発研究はここ 20 数年間 にわたる日本および世界各国における 精力的な研究活動によって, プラズマ 物理の基礎的研究から，プラズマ装置 工学そして炉工学技術開発へと進展し た。これらの成果は, 極めて近い将来 での核融合での発電(プラズマエネル ギー発電)の実現の可能性を示すすの である。現在, 核融合炉の実用化に向

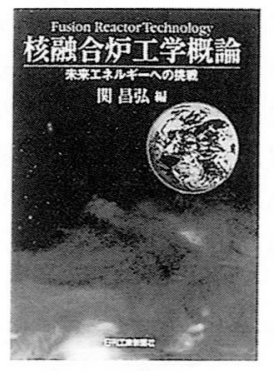
けた更なる重要なステップである実験炉, 具体的には国際熱核 
融合実験炉(ITER)の建設計画が大きく動こうとしている。 核融合炉工学は，多くの技術分野を包含する総合科学を基盤 にしているため，それらを理解するためには多岐にわたる理工 学分野の理解が不可欠となる。しかし，これまで急速な進展が 継続したこともあり，核融合炉工学全体をきちんと概説したす のがなく, 核融合炉技術を最新の知見を踏まえて包括的にまと めた概説書の出現が待たれていた。本書はこの要求を見事に満 たしており，核融合研究者はもちろん，これから核融合を学ば うとしている人たちにとって最適な教科書といえる。

本書は，核融合炉技術開発に直接携わってきた日本原子力研 究所の第一線の研究者によって書かれており, 最先端の技術情 報がわかりやすく解説されている。

構成は第 1 部と第 2 部からなり, 第 1 部では, 核融合炉の原 理と運転, その誕生までのシナリオがこれまでの経緯や今後の 展望も含めて概説してある。本書の主題である第 2 部では，炉 工学技術の有機的結合関係が理解できる構成になっており, こ れ 1 冊で核融合の原理および核融合炉工学の各専門分野の概要 が把握できるように配慮されている。核融合関係者はもちろ ん, 核融合に直接関係のない会員の方にも, 様々な理工学的七 ントを含む総合科学技術書である本書を一読されることを扔勧
めしたい。具体的な目次は次の通りである。 核融合炉の誕生

第 1 章 人類の進歩とエネルギー

第 2 章 太陽で起きている核融合と地球で目指す核融合 第 3 章 核融合炉が成立する条件

第 4 章 実現に最む近いトカマク型核融合炉

第 5 章 核融合炉実用化への展望

\section{核融合炉を支える技術}

第 6 章 プラズマを閉じ込め磁場を作る超伝導コイル 第 7 章 高純度プラズマを保持する真空容器 第 8 章 プラズマを超高温にする加熱·電流駆動装置 第 9 章 超高温プラズマ状態を見て繰る計測・制御システム 第10章 エネルギーを取り出し燃料を作るブランケット 第11章 ブランケットを支える構造材料と然料增殖材料 第12章 高温に耐え真空容器などを守るプラズマ対向機器 第13章 重水素やトリチウムを効率よく利用する燃料循環シ ステム

第14章 核融合炉を安全に保守する遠隔保守ロボット

第15章 核融合炉の安全性を確保する放射線防護システム

（京大·香山 晃）

\title{
々モンテカルロ法による粒子シミュレーションの現状と課題々
}

\section{「モンテカルロ法による粒子シミュレーション」研究専門委員会報告書}

\author{
2002 年 1 月発行
}

A 4 判260頁, 会員特価 4,000 円 (定価 5,000 円), 送料 ·税別

(ㄷ)希望の方は学会事務局へ。(FAX 03-3581-6128,E-mail : atom@aesj.or. jp)

原子力分野では，連続エネルギーモンテカルロコード(MCNPやMVP)の普及に伴い，さまざまな研究分野におい て高精度な評価が可能となり，最近では，特に国際熱核融合実験炉や大型原子炉の炉心解析のように実規模大型体系 にも適用されている。高エネルギー加速器の設計や関連研究施設の設計のため, 高エネルギー中性子断面積の評価や 高エネルギー粒子輸送計算コードが開発され，従来の経験式での設計評価の時代から輸送計算による設計評価の時代 に移りつつある。本報告書は本委員会が主催した第 2 回モンテカルロシミュレーション研究会(2001. 5. 24-25, 三菱 総研)のプロシーディングであり, 最近の国内の研究成果(本委員会での調査・検討結果を含む)ばかりか, 中国とイン ドネシアにおけるモンテカルロ研究の現状む記されている。

\section{目次}

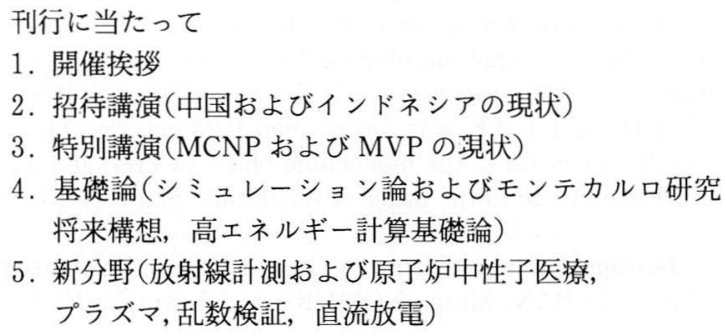

1. 開催挨拶

2. 招待講演(中国およびインドネシアの現状)

3. 特別講演 (MCNP およびMVP の現状)

4. 基礎論 (シミュレーション論およびモンテカルロ研究 将来構想, 高エネルギー計算基礎論)

5. 新分野(放射線計測および原子炉中性子医療, プラズマ, 乱数検証, 直流放電)

6. 高エネルギー(高エネルギーファイルおよびNMTC/JAM, 宇宙被曝, 大型加速器建設)

7. 原子炉 (ITER, HTTR, JMTR)

8. 臨界・遮蔽(未臨界評価法, 再処理施設未臨界, 中間眝蔵施設遮蔽

9. まとめ

編集者あとがき 